\title{
Eser Değerlendirmesi: Saadettin ÖZDEMİR, Engelliler ve Din: İstatistiksel Verilerle Engellilerin Din Eğitimindeki Mevcut Durumu, C Planı Yayınları, İstanbul 2016, 143 s.
}

(ISBN: 9786059883504)

Her insan farklı özelliklerle dünyaya gelmekte ve bu özellikler insanların kendilerini ve yaşadıkları dünyayı algılamalarında etkili olmaktadır. Engellilik hali de bireyin hayatını kısmen ya da tamamen etkileyen, kendini ve hayatı algılama biçimine yön veren bir durumdur. Aynı zamanda engellilik, bireyin toplum tarafından nasıl algılanacağını da belirleyebilmektedir. $\mathrm{Bu}$ algılar insandan insana ya da farklı toplumlarda değişiklik gösterebilir. Bazen engelli bireyler, diğer insanların acıma ve merhamet duygularıyla; bazen de toplumsal yaşamın dışında görülme, yok sayılma gibi olumsuz tutumlarla karşılaşabilmektedir. Bu durum, engelli bireyin toplum içinde nasıl algılanacağını belirleyen inanç, kültür, toplumsal yaşam gibi farklı unsurların olduğunu göstermektedir. Örneğin ilkel toplumlarda bireyin topluma katkısı esas alınmakta olduğu için pragmatist bir bakış açısıyla topluma katkı sağlayamadığı düşünülen engelli bireyler, toplum için bir yük olarak algılanabilmişlerdir. İnsanlar, engellilere karşı besledikleri olumsuz düşüncelerini destekleyen argümanları bazen dini öğretilerinde de bulmuşlardır. Engelli çocukların Tanrının bir cezası olarak görüldüğü birtakım inanışlar engelli bireyin hem kendilik algısını hem de toplum nezdindeki algısını etkilemiştir.

Modern toplumlarda ise engellilere yönelik olumsuz bakışın geçmiş dönemlerle kıyaslandığında daha az olduğu ifade edilebilir. Konuyla ilgili hukuki düzenlemeler, toplumsal hayata engellilerin katılımı için alınan önlemler, eğitim alanındaki gelişmeler engellilerle ilgili olumlu bir yaklaşımı desteklemektedir. Bununla birlikte engelli bireylerin toplumsal yaşamda aşmaları gereken hala pek çok engel bulunmaktadır. Türkiye'de 2011 TÜİK verilerine göre toplam nüfusun yaklaşık \%7'sini engelli bireyler oluşturmaktadır. Onlar başta istihdam ve eğitim olmak üzere pek çok konuda hala toplumu oluşturan diğer bireylerle eşit şansa sahip görünmemektedir. Bununla birlikte son zamanlarda engellik konusundaki farkındalığın arttığını da ifade etmek gerekir. Engelli bireylerle ilgili hukuki düzenlemeler yanında akademik çalışmalar da son dönemde gittikçe artmaktadır.

Özel eğitim alanıyla birlikte, dezavantajlı gruplara sunulan sosyal ve dini hizmetler, manevi danışmanlık dini rehberlik gibi alanlarda oldukça yoğun çalışmaların olduğu

\footnotetext{
* Dr., Ankara Üniversitesi, İlahiyat Fakültesi, Felsefe ve Din Bilimleri Bölümü, Din Eğitimi, fcapci@ankara.edu.tr
} 
görülmektedir. Bu akademik çalışmalardan bazıları, dindarlığın engellilik durumu karşısında daha olumlu işlev gördüğünü ortaya koymakta, engelliliğe yüklenen olumsuz bakış açısının dini inançların yetersizliği ile ilişkili olabileceğini de göstermektedir. ${ }^{1}$ Ülkemizde de özellikle son dönemlerde manevi ve dini danışmanlık hizmetleri ve dini sosyal hizmetler gibi konularda çeşitli çalışmalar yapılmaktadır. ${ }^{2}$ Süleyman Demirel Üniversitesi İlahiyat Fakültesi Felsefe ve Din Bilimleri Din Eğitimi Anabilim Dalı Öğretim Üyesi Doç. Dr. Saadettin Özdemir de, çalışmalarını özellikle dini sosyal hizmetler ile engelliler ve din eğitimi alanlarında yoğunlaştırmış bir akademisyendir. Özdemir, konuyla ilgili çeşitli tebliğ, sunum ve makalelerinin ardından 2016 yılında Engellilik ve Din başlıklı kitabını yayınlamıştır. Kitap, engelli bireylere yönelik din hizmetlerinin yeterliliğini istatistiksel verilerle ortaya koymaya çalışmaktadır.

Kitap, giriş hariç iki bölümden oluşmaktadır. Giriş kısmında araştırmanın önemi, yöntemi ve elde edilen verilerin analizine dair bilgiler paylaşılmaktadır. Kitabın ilk bölümü olan kavramsal çerçevede işitme, görme ve ortopedik engellilerin özellikleri ile ilgili bilgilere yer verilmiş, İslam'ın engellilere yaklaşımı Kur'an ve hadisler çerçevesinde ele alınmıştır. Bu çerçevede Kur'an'da insana verilen değer ve önemden bahsedilmiş, Allah'ın insana verdiği nimetlere şükretmesi gerektiği belirtilmiştir. Bu kapsamda Kur'an'’n engellilik konusuna bakışının fizyolojik bir bakış açısı olmayıp dini bir perspektif çerçevesinden olduğu belirtilmiştir. Kur'an'da geçen “görmezler işitmezler” gibi ifadelerin maddi olarak bir görme ya da işitme şeklinde değil, insanın gerçeği ve hakikati görememesi anlamında kullanıldığına örnekler verilmektedir. Böylece Kur'an'ın hiçbir şekilde maddi engelliliği bir eksiklik olarak görüp eleştiri konusu yapmadığına vurgu yapılmaktadır. "Hadislerde Engellilik" başlığı altında ise Hz. Peygamberin engellilere yönelik söz, tutum ve davranışlarına örnekler verilmiştir. $\mathrm{Bu}$ çerçevede $\mathrm{Hz}$. Peygamberin engellilere yönelik tutumu, sadece bir kişiye acıma ve onun problemlerini çözmenin ötesinde devletin ve toplumun neleri nasıl yapabileceğine dair önerileri kapsamaktadır. İslam'ın engellilere bakışını ortaya koymaya çalıştı̆̆ kolaylıklardır. Bu başlık altında İslam'ın her türlü engel grubuna göre akıl ve mantık kuralları çerçevesinde çözümler ürettiği örneklerle açıklanmaya çalışılmaktadır. Birinci bölümün son başlığı olan "İslam Kültür Tarihinde Engelliler" de ise peygamberin vefatından itibaren İslam tarihinin farklı dönemlerinde engellilerle ilgili yapılan çeşitli uygulamalardan örnekler sunulmaktadır. Böylece İslam kültür coğrafyasında engellilerin topluma entegre edilmeye çalışıldığı vurgulanmaktadır.

\footnotetext{
${ }^{1}$ Linda L Treloar, “Engellilik, Dini İnançlar ve Kilise: Engelli Yetişkinlerin ve Aile Bireylerinin Deneyimleri”, çev. Mehmet Bahçekapıl1, İstanbul Üniversitesi Illahiyat Fakültesi Dergisi, 2012, C. 27, ss.211-230.

${ }^{2}$ Manevi danışmanlık kongresi, Dezavantajlı Gruplar Psiko-Sosyal ve Manevi Bakım gibi çalışmalar sayılabilir. Bkz. İhsan Çapcioğlu, F. Zeynep Belen (2016) (ed.), Dezavantajll Gruplar Psiko-Sosyal ve Manevi Bakım,

Ankara: Grafiker Yayınları.
} 
İkinci bölüm “Bulgular ve Yorumlar” başlığına sahiptir. Bu bölüm, Özdemir'in Isparta merkez ve ilçelerinde yaşayan ve tesadüfi örnekleme ile seçilen görme, işitme ve ortopedik engelli 294 bireye yapmış olduğu anket uygulamasının verilerine ayrılmıştır. Araştırmada veri türüne göre korelasyon $t$ testi ve tek yönlü varyans analizi (anova) yapılmıştır. Elde edilen bulgular tablolar halinde okuyucuya sunulmuş, daha sonra tablodaki veriler kısaca değerlendirilmiştir. Araştırmanın boyutları ayrı birer altında yorumlanarak şu sonuçlara ulaşılmıştır:

1. Dini bilgileri öğrenme boyutu: Araştırma sonucuna göre engelliler, engelleri ile ilgili ve gündelik hayatta karşılaştıkları dini kaynaklı sorunlara çözüm bulmada ihtiyaç duydukları dini bilgilerini genel olarak yetersiz bulmaktadırlar. Ayrıca onlar, öğrenmek istedikleri, ilgi duydukları, merak ettikleri veya problem olarak gördükleri konularda din görevlilerinden yeterli yardımı göremediklerini de ifade etmektedirler. Aynı çerçevede Diyanet İşleri Başkanlığının engellilere yönelik hizmetlerinin yetersiz olduğu da düşünülmektedir. Buna göre engelliler dini bilgileri edinme konusunda dini kurumlardan yeterli oranda yararlanamamaktadırlar. Bu durumun sebebi, engellilere din hizmeti sunabilecek yeterlikte din görevlisinin olmayışı olarak belirlenmektedir.

2. DKAB derslerinin engellilerin din eğitimine katkı boyutu: Engelliler örgün eğitim kurumlarında verilen DKAB derslerindeki dini bilgileri genel olarak yeterli bulmamaktadırlar. Araştırmada bu durum, DKAB dersi müfredatlarında genel dini konuların yer alması ile ilişkilendirilmiştir.

3. Ibadetlerle ilgili bilgileri ögrenme boyutu: Engelliler günlük hayatta ibadetlerle ilgili ilmihal bilgisi olarak nitelendirilen dini bilgilere ihtiyaç duyduklarını belirtmektedirler. Engellilerin yaklaşık üçte ikisi ilmihal kitaplarını engellilik açısından yetersiz bulurken, duayla ilgili bilgiler genel olarak yeterli görülmektedir.

4. Ibadetlerin yapılışı esnasında karşılaşılan fiziki engeller boyutu: Engelliler ibadet mekanlarına ulaşabilme noktasında kendileri açısından mimari düzenlemeleri yetersiz bulmaktadırlar. Yetersiz bulanlar özellikle ibadet mekânlarına ulaşım problemiyle karşılaşan ortopedik ve görme engelli bireylerdir. $\mathrm{Bu}$ veri, son dönemlerdeki çalışmalara rağmen mimari düzenlemelerin hala istenilen düzeyde olmadığını göstermektedir. İbadet mekânlarının iç dizaynı ise engelliler tarafından genel olarak yeterli bulunmuştur. Bu durum ise İbadethanelere ulaştıktan sonra problemlerin büyük oranda çözüldüğünü göstermektedir. Bununla birlikte iç mekanda yer alan abdest yerleri gibi kullanım alanları yeterli bulunmamaktadır.

5. Engellilere yönelik dini yayınların yeterliliği boyutu: Dini içerikli yayınların yetersizliği, engellilerin çoğunluğu tarafından kabul edilen bir görüştür. Yetersiz bulunan durum, engellilerin karşılaşmış oldukları sorunlara dini içerikli yayınlarla 
çözüm bulunmamasıyla ilgilidir. Engelliler DİB yayınlarını da yeterli bulmamaktadırlar. $\mathrm{Bu}$ yayınlar çoğunlukla genel gündem çerçevesinde oluştuğu, engellilerin özel ilgi alanlarına hitap etmediği düşünülmektedir. DİB'in yayınlar konusunda yetersiz bulunması bu kurumun verdiği fetvalar konusunda da geçerlidir. Halkı din konusunda aydınlatma görevi bulunan DİB'in dezavantajlı gruplar olarak nitelenen engellilere yönelik bilgi akışının gerçekleştirememiş olması iletişim konusunda bir problemin yaşandığını göstermektedir.

Özdemir, kitabın sonuç ve öneriler kısmında ülkemizde engellilerin karşılaşıı̆ı çeşitli sorunlara yeniden değinmekte, bu engellerin başında eğitim ve din eğitimi ile ilgili konuların geldiğini belirtmektedir. Araştırma verilerine göre de görme, ortopedik ve işitme engelli bireylerin din eğitimiyle ilgili yetersizliklerinin olduğu kendilerine sunulan hizmetleri yeterli bulmadıkları sonucuna varılmaktadır. Özellikle din eğitimiyle ilgili yetersizlikleri dini bilgileri öğrenme, ibadet mekânlarında karşılaşlan zorluklar ve dini yayınların yetersizliği başlıkları altında toplanmaktadır. 